\title{
Comparison of floor bacterial load in different types of rabbit cages
}

\section{Divyalakshmi*}

Department of Livestock Production Management, Madras Veterinary College, Chennai-600007 (Tamil Nadu), India

\section{N. Kumaravelu}

Department of Livestock Production Management, Madras Veterinary College, Chennai-600007 (Tamil Nadu), India

\section{Thanga.Thamil Vanan}

Department of Livestock Production Management, Madras Veterinary College, Chennai-600007 (Tamil Nadu), India

\section{P.Tensingh Gnanaraj}

Registrar, Tamil Nadu Veterinary and Animal Science, Madhavram Milk Colony, Chennai-600051 (Tamil Nadu), India

*Corresponding author. E-mail: nandhi7121989@gmail.com

\begin{abstract}
Rabbits are housed on various types of cages including single tier, multi- tier cages etc. The effect of housing system on the floor bacterial load is variable, and its effect on animal production is limited. An attempt has been made to evaluate and compare the floor bacterial load between single-tier and multi-tier caging system in rabbitary. The study was carried out in rabbitary which housed broiler rabbits. The samples were taken in sterile cotton tipped swabs. The floor bacterial load was determined by dilution method where serial dilutions were done with sterile normal saline. An aliquot of $1 \mathrm{ml}$ was taken from dilution and poured in sterile petri plates in triplicate and mixed with liquefied sterilized plate count agar. Following incubation, the bacterial colonies were counted. The bacterial load in the single-tier was comparatively lower than the multi-tier cage even before washing of cages. There was significant difference $(P<0.01)$ in the floor bacterial load before $\left(1.73 \times 10^{12} \pm 0.30\right)$ and after water wash $\left(1.35 \times 10^{11} \pm 0.29\right)$ and between single $\left(1.50 \times 10^{9} \pm 0.30\right)$ and multi-tier cages $\left(1.35 \times 10^{11} \pm 0.29\right)$. The bacteria up to genes level found using Hi-Media bacterial kit were Staphylococcus aureus, Staphylococcus epidermidis, Flavobacterium sp, Micrococcus sp, Proteus sp, Mannheimia sp, Klebsiella sp, Bordetella sp, Bacillus sp, Actinomyces sp, Cornybacterium sp and Pseudomonas sp. This study concluded that reduced bacterial load found in single tier may be due to good aeration and better handling facilities. In single tier cage the dung and urine gets settled at the floor which facilities easy washing which slows down the bacterial growth.
\end{abstract}

Keywords: Bacterial load, Caging system, Dilution method, Multi-tier, Rabbitary, Single tier

\section{INTRODUCTION}

Intensification of animal housing in India is gaining popularity in order to mechanize the livestock production activities. The enriched housing system in rabbitary not only enhances the animal welfare but also increases the animal production. Consequently, the rabbits are housed on various systems of caging, owing to lack of space. The different systems include single tier, multi-tier and $\mathrm{M}$ Type cages. Although multi-tier cage has greater advantage of greater stocking density, the ease in handling and cleaning the cages are comparatively less. The greatest disadvantage of the cage system is that rabbits are exposed to high temper-

\section{Article Info}

DOI:10.31018/jans.v10i4.1916

Received: October 8, 2018

Revised: November 11, 2018

Accepted: November 21, 2018

\section{How to Cite}

Divyalakshmi, D. et al. (2018). Comparison of floor bacterial load in different types of rabbit cages. Journal of Applied and Natural Science, 10(4): 1226-1229 


\section{MATERIALS AND METHODS}

Experimental location: The experiment was conducted in Livestock Farm Complex, Madhavaram Milk Colony, Chennai, Tamil Nadu.

Experimental housing design: The rabbit facility consisted of a conventional shed with king truss and full monitor roofing. Soviet chinchilla and New Zealand White breeds of rabbit were maintained for instructional and fryer production. The parent stock of either breeds were maintained separately for the getting bunny crop yield. The bunnies meant for fryer production were weaned at the age of one month or immediately after attaining the minimum body weight of 250 gms. The weaned bunnies were housed in separate cages in groups till two months to avoid weaning stress, since rabbits are colonial animals. The specified facility housed different stages of rabbits in both single tier and multi tier cages. For experimental purpose double rows of single tier cages with each row having a carrying capacity of ten cages was selected. Another six multi-tier cages with three cages were selected. The floors of the cages were made of galvanized iron having $1.25 \mathrm{x}$ $1.25 \mathrm{~cm}$ mesh diameter. The experimental cages housed uniform sized animals of either sex, breed and were aged between 4 months to one year. Male rabbits were housed in single per cage and females were housed two per cage to avoid infighting. The rabbits' were provided with a floor space of $1.96 \times 1.64 \mathrm{ft}$.

Sampling procedure and methodology: Floor swabs were taken randomly in three different places inside the cage (Area 1, Area 2 and Area3) before and after manual water cleaning during the morning hours, using individual sterile cotton tipped swabs by swabbing within $10 \mathrm{~cm}^{2}$ area as per Gibson et al.,(1999). The sample was transported aseptically from sampling site to the laboratory within one hour and the test was carried on. The samples were collected twice in a week and the procedure was continued for a period of one month. The floor bacterial load was determined by dilution method where serial dilutions were done with sterile normal saline. The dilutions were made serially up to $10^{-12}$ dilutions. An aliquot of 1 $\mathrm{ml}$ was taken from last three dilutions $\left(10^{-10}, 10^{-11}\right.$, $10^{-12}$ ) and poured in sterile petri plates in triplicate and mixed with $20 \mathrm{ml}$ of liquefied sterilized plate count agar.

$\begin{array}{ll}\text { Composition of plate count agar (Hi-Media) } \\ \text { Tryptone } & 5.0 \mathrm{gms} / \mathrm{lt} \\ \text { Yeast extract } & 2.500 \mathrm{gms} / \mathrm{lt} \\ \text { Dextrose } & 1.00 \mathrm{gms} / \mathrm{t} \\ \text { Agar } & 15.00 \mathrm{gms} / \mathrm{tt} \\ \mathrm{pH} & 7.0 \pm 0.2\end{array}$

After solidification of agar, the plates were incubated in inverted position at $37^{\circ} \mathrm{C}$ for 24 hours. After incubation, bacterial cells grow into distinct colonies, which were counted with colony counter.
The distinct colonies were sub-cultured individually. The pure sub-culture was subjected to analysis in bacterial kit. The individual bacterial kits which contained the various bio-chemical tests in small slots were smeared with the pure culture of the bacterial colony and were incubated over night at $37^{\circ} \mathrm{C}$ for 24 hours for the colour change. Following the colour change the bacteria was identified. All the laboratory procedures were done in laminar air flow cabinet. The data collected were subjected to statistical analysis as per the method of Snedecor and Cochran (1994).

\section{RESULTS AND DISCUSSION}

The mean \pm S.E of the microbial load of single-tier vs. Multi-tier cage is presented in Table 1. By statistical analysis it was found that there was highly significant difference $(P<0.01)$ in microbial load between before and after manual cleaning of the floors in both single and multi-tier cages. The bacterial isolates was found using (Hi-Media) bacterial isolation kit (Fig 2). The bacteria up to genes level which were found are Staphylococcus aureus, Staphylococcus epidermidis, Flavobacterium $\mathrm{sp}$, Micrococcus sp, Proteus sp, Mannheimia sp, Klebsiella sp, Bordetella sp, Bacillus sp, Actinomyces $\mathrm{sp}$, Cornybacterium $\mathrm{sp}$ and Pseudomonas sp.

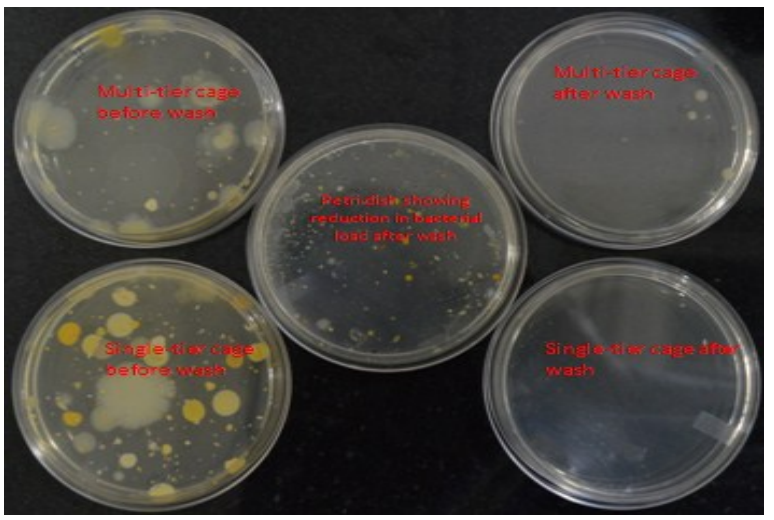

Fig. 1. Petri plates showing reduction in floor bacterial load before and after water wash.

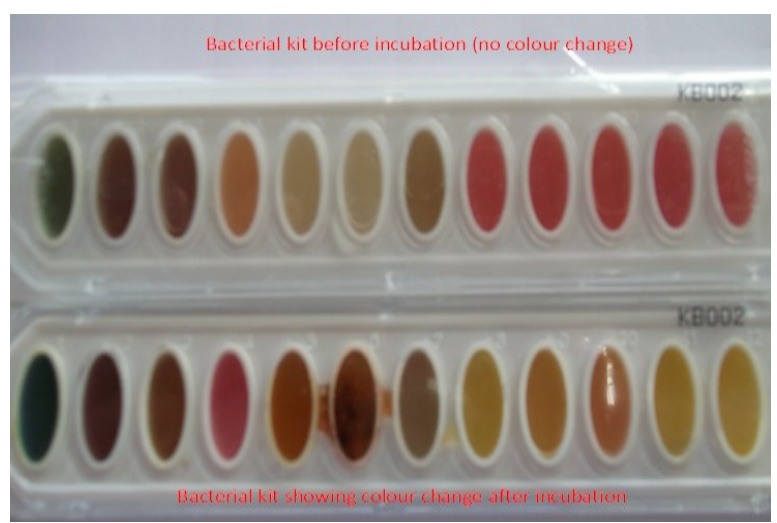

Fig. 2. Bacterial isolation kit used for identification of bacteria showing colour change before and after incubation. 
Divyalakshmi, D. et al. / J. Appl. \& Nat. Sci. 10 (4): 1226-1229 (2018)

Table1. Mean \pm S.E. $(n=24)$ of floor bacterial load in multi-tier and single tier cage system in rabbitary.

\begin{tabular}{lllll}
\hline \multirow{2}{*}{ Treatment } & Multi-tier cage & & Single-tier cage & \\
\cline { 2 - 5 } & Before wash & After wash & Before wash & After wash \\
\hline Area 1 & $1.88 \times 10^{11 \mathrm{~b}} \pm 0.32$ & $1.07 \times 10^{10 \mathrm{~b}} \pm 0.35$ & $2.42 \times 10^{10 \mathrm{~b}} \pm 0.39$ & $2.48 \times 10^{9 \mathrm{~b}} \pm 0.33$ \\
Area 2 & $1.89 \times 10^{11 \mathrm{~b}} \pm 0.32$ & $1.21 \times 10^{10 \mathrm{~b}} \pm 0.34$ & $2.17 \times 10^{10 \mathrm{~b}} 0.46$ & $5.26 \times 10^{9 \mathrm{~b}} \pm 0.45$ \\
Area 3 & $1.73 \times 10^{12 \mathrm{a}} \pm 0.30$ & $1.35 \times 10^{11 \mathrm{a}} \pm 0.29$ & $1.42 \times 10^{10 \mathrm{a}} \pm 0.31$ & $1.50 \times 10^{9 \mathrm{a}} \pm 0.30$ \\
\hline
\end{tabular}

Means bearing different superscript in the same row and column differ significantly

There was highly significant difference $(P<0.01)$ between the sampling areas within a cage type (Fig 1). This indicated that the microbial load was lower in single-tier when compared to multi-tier. Blessy (2014) compared the floor microbial load between slatted and conventional goat pen and found that floor microbial load was lower in poly urethane slatted floor. Blessy (2014) concluded that microbial load in conventional goat house with concrete floor was higher than elevated wooden and polyurethane slatted floors. The reason may be due to presence of fodder left overs and direct contact of floor with dung and urine. Similar observations were reported by Pritchard et al., (1981) in calf shed and Yasotha (2000) in sheep pen. It is evident that the microbial load in multi-tier cage was higher than single tier cage. The reason may be due to stocking density and limited air flow in the lowest cage in multi-tier cage. The successful survival of airborne bacteria depends on factors such as temperature, relative humidity, oxygen concentration and sunlight exposure. High relative humidity $(70-90 \%)$ and ultra violet light have lethal effect towards bacteria and aerosol dissemination of bacteria into different types of atmosphere can also affect the survival characteristics of the organism. Atmospheric turbulence, responsible for micro-organisms is strongly influenced by local atmospheric conditions and diurnal variation in solar irradiance reaching the ground. Ventilation system has a significant effect on the indoor levels on air borne fungi (Tang, 2009). Similarly higher microbial load was observed in conventional floor in poultry house by Madelin and Wathes (1989). The higher microbial count in Area 3 may be due to the accumulation of faecal matter and the presence of moisture which favours the multiplication of bacteria at a faster growth. This is in agreement with $\mathrm{Li}$ et al., (2016) who showed that a large number of airborne aerobic bacteria were present inside the enclosed rabbit shed and the type of environment may pose a serious threat to the health of exposed animals and individuals. This is in agreement with the findings of Gautam et al., (2011) who mentioned that the slower water replacement and available standing water leads to a greater pathogen load. Ayscue et al., (2009) also indicated that growth of $\mathrm{E}$. coli $\mathrm{O} 157: \mathrm{H} 7$ in water and external environment are highly dependent on the feedlot pen of dairy cattle housing and design. The reduced bacterial load found in single tier may be due to the good aeration and better handling facilities. In single tier cage the dung and urine gets settled at the floor which facilities easy washing which slows down the bacterial growth. Hence it could be concluded that floor bacterial load in single tier cage is significantly lower when compared to multi-tier cage.

\section{Conclusion}

A study was conducted to compare the floor bacterial load between single tier and multi-tier caging system in rabbitary. The bacterial load was found using dilution method. It was found that significant difference $(P<0.01)$ in the floor bacterial load was observed before $\left(1.73 \times 10^{12} \pm 0.30\right)$ and after water wash $\left(1.35 \times 10^{11} \pm 0.29\right)$ and between single $\left(1.50 \times 10^{9} \pm 0.30\right)$ and multi-tier cages $\left(1.35 \times 10^{11} \pm 0.29\right)$. Though multi-tier cage cages provided the opportunity of space saving, it harbours bacteria and other microbes if improperly handled. Further data on air borne pathogenic bacterial load could be assessed to have a complete understanding on the issue on single and multi- tier cages. Hence it was concluded that the bacterial load was much reduced in single tier cage than the multi-tier cage indicating their use in modern rabbit houses.

\section{REFERENCES}

1. Ayscue, P., Lanzas, C., Ivanek, R. and Grohn., Y.T. (2009). Modeling on-farm Escherichia coli 0157:H7 Population Dynamics. Foodborne Pathog. Dis. 6 (4):461-470. https://doi.org/ 10.1089/fpd. 2008.0235.

2. Blessey, P.G., (2014). Performance of weaner kids in different stall fed housing systems. M.V.Sc., Thesis submitted to Tamil Nadu Veterinary and Animal Sciences University, Chennai-51

3. Gautam, R., Yaghoub, M.B., Neill, W.H., Dopfer, D., Kaspar C. and Ivanek R. (2011). Modeling the effect of seasonal variation in ambient temperature on the transmission dynamics of a pathogen with a freeliving stage: example of Escherichia coli $0157: \mathrm{H} 7$ in a dairy herd. Prev Vet Med. 102(1):10-21. https:// doi.org/10.1016/j.prevetmed.2011.06.008

4. Gibson, H., Taylor, J.H., Hall, K.E., and Holah, J.T. (1999). Effectiveness of cleaning techniques used in the food industry in terms of the removal of bacterial biofilms. J Appl Microbiol. 87(1):41-48. https:// doi.org/10.1046/j.1365-2672.1999.00790.x.

5. ICAR Handbook of Animal Husbandry. (2014). $4^{\text {th }}$ revised edn., New Delhi. pp. 388.

6. Lamidi , W.A. (2015). Environment and Different Management Systems in Rabbit Does- A Review. AASCIT. 1(3): 51-56. https://doi.org/ www.aascit.org/ 
journal/ajepm.

7. Li, S., Li, M.Y., Mu,T. And Miao, Z.M. (2016). Technical note: Concentration and composition of airborne aerobic bacteria inside an enclosed rabbit shed. World Rabbit Sci. 2016, 24: 71-75. https:// doi:10.4995/ wrs. 2016.4170

8. Madelin,T.M. and Wathes, C.M. (1989). Air hygiene in a broiler house: Comparison of deep litter with raised netting floors. Br. Poultry Sci., 30: 23-37. https://doi.org/10.1080/00071668908417122

9. Pritchard,D.G., Carpenter, C.A., Morzaria, S.P., Harkness, J.W., Richards, M.S. and Brewer, J.I. (1981). Effect of air filtration on respiratory disease in intensively housed veal calves. Vet. Rec., 109: 5-9. https://doi.org/ 10.1136/vr.109.1.5

10.Sastry, N.S.R. and Thomas,C.K. ( 2015). Livestock production and management, $5^{\text {th }}$ revised edn., Kalyani publishers, New Delhi. pp. 585.

11.Snedecor, G.W. and Cochran, W.G. (1994). Statistical Methods, $8^{\text {th }}$ Ed. Oxford and IBH publishing Co. Pvt. Ltd., New Delhi, India, pp.254-268.

12.Tang, J.M. (2009). The effect of environmental parameters on the survival of airborne infectious agents. J. R. Soc. Interface, 6: 737-746. https:// doi.org/10.1098/rsif.2009.0227.

13. Yasotha, A. (2000). Air pollution level in sheep pens. M.V.Sc., Thesis submitted to Tamil Nadu Veterinary and Animal Sciences University, Chennai-51 